\title{
Molecular cytogenetic characterization and fusarium head blight resistance of five wheat-Thinopyrum intermedium partial amphiploids
}

Hui Wang ${ }^{1}$, Shuwei Cheng ${ }^{1}$, Yue Shi', Shuxin Zhang ${ }^{1}$, Wei Yan ${ }^{1}$, Weifu Song ${ }^{2}$, Xuefeng Yang ${ }^{2}$, Qingjie Song ${ }^{2}$, Bo Jang ${ }^{1}$, Xiaoyue $\mathrm{Qi}^{1}$, Xinling $\mathrm{Li}^{1}$, Bernd Friebe ${ }^{3}$ and Yanming Zhang ${ }^{1 *}$

\begin{abstract}
Background: Partial amphiploids created by crossing octoploid tritelytrigia( $2 \mathrm{n}=8 \mathrm{x}=56$, AABBDDEE) and Thinopyrum intermedium $\left(2 n=6 x=42, S t S t J J J^{S} S^{S}\right)$ are important intermediates in wheat breeding because of their resistance to major wheat diseases. We examined the chromosome compositions of five wheat-Th. intermedium partial amphiploids using GISH and multicolor-FISH.

Results: The result revealed that five lines had 10-14 J-genome chromosomes from Th. intermedium and 42 common wheat chromosomes, using the J-genomic DNA from Th. bessarabicum as GISH probe and the oligo probes pAs1-1, pAs1-3, AFA-4, (GAA) 10, and pSc119.2-1 as FISH probe. Five lines resembled their parent octoploid tritelytrigia $(2 \mathrm{n}=8 \times=56, \mathrm{AABBDDEE})$ but had higher protein contents. Protein contents of two lines HS2-2 and HS2-5 were up to more than 20\%. Evaluation of Fusarium head blight (FHB) resistance revealed that the percent of symptomatic spikelets (PSS) of these lines were below 30\%. Lines HS2-2, HS2-4, HS2-5, and HS2-16 were less than 20\% of PPS. Line HS2-5 with $14 \mathrm{~J}$-genome chromosomes from Th. intermedium showed the best disease resistance, with PSS values of $10.8 \%$ and $16.6 \%$ in 2016 and 2017 , respectively.
\end{abstract}

Conclusions: New wheat-Th. intermedium amphiploids with the J-genome chromosomes were identified and can be considered as a valuable source of FHB resistance in wheat breeding.

Keywords: Thinopyrum intermedium, Common wheat, Partial amphiploids, Fusarium head blight, In situ hybridization

\section{Background}

Common wheat (Triticum aestivum $\mathrm{L}, 2 \mathrm{n}=6 \times=42$, AABBDD) is represented by a narrow germplasm base, which causes vulnerability to biotic and abiotic stresses $[23,35,50,55]$. This narrow gene pool minimizes opportunities for developing genetic resistance to diseases.

\footnotetext{
*Correspondence: yanmingz@hrbnu.edu.cn

${ }^{1}$ Key Laboratory of Molecular Cytogenetics and Genetic Breeding

of Heilongjiang Province, College of Life Science and Technology, Harbin Normal University, Harbin 150025, China

Full list of author information is available at the end of the article
}

However, wild relatives of wheat provide a valuable reservoir of genes for cultivar improvement via wide hybridization [59, 69]. The wheatgrass, Th. intermedium (Host) Barkworth and D. R. Dewey $(2 \mathrm{n}=6 \times=42)$ [syn. Agropyron intermedium (Host) Beauvoir, or Elytrigia intermedia (Host) Nevski, $2 \mathrm{n}=6 \times=42 \mathrm{StSt} / J J^{\mathrm{S}} \mathrm{J}^{\mathrm{S}}$ ], is a perennial autoallo-hexaploid species that is an important source of genetic variability for improving cultivated wheat. It has been used extensively for hybridization with bread wheat and durum wheat, and numerous useful genes have been transferred to wheat $[27,51,65]$. Many derivatives have original author(s) and the source, provide a link to the Creative Commons licence, and indicate if changes were made. The images or other third party material in this article are included in the article's Creative Commons licence, unless indicated otherwise in a credit line to the material. If material is not included in the article's Creative Commons licence and your intended use is not permitted by statutory regulation or exceeds the permitted use, you will need to obtain permission directly from the copyright holder. To view a copy of this licence, visit http://creativecommons.org/licenses/by/4.0/. The Creative Commons Public Domain Dedication waiver (http://creativeco mmons.org/publicdomain/zero/1.0/) applies to the data made available in this article, unless otherwise stated in a credit line to the data. 
been produced from wheat-Th. intermedium hybrids, such as octoploid and hexaploid partial amphiploids and chromosome addition, substitution and translocation lines $[10,60]$. Th. intermedium provides resistance against a wide spectrum of fungal pathogens (wheat leaf rust, stripe rust, stem rust, powdery mildew and eyespot; immunity to smut, leaf blight, root rot) and barley yellow dwarf virus and stripe mosaic viruses $[13,17,23,40$, 41, 67]. Additionally, Th. intermedium is one of the most advanced examples of a recently domesticated perennial grain crop [18]. At present, numerous intergeneric hybrids and cytogenetic stocks have been developed from wheat-Th. intermidium crosses, including partial amphiploids $[4,22,56]$, chromosome addition lines [29, $44]$, substitution lines [31, 38, 45], and translocation lines $[30,46]$.

Fusarium head blight (FHB), caused mainly by the fungus Fusarium graminearum Schwabe, is a destructive disease of wheat and poses a serious threat to the health of consumers of wheat products [2, 49]. Genetic studies in wheat have identified more than 200 useful loci for improvement of complex traits, such as FHB. Unfortunately, many of them remain unused or under-utilized in plant breeding programs mainly because of the complex nature of resistance [6, 7]. Extensive efforts have been made to utilize host resistance for managing this disease. At present, the most effective and widely used QTL for FHB resistance is located on chromosome 3BS of the Chinese wheat varieties Sumai 3 and Wangshuibai $[1,34,70]$, which have been further investigated and several additional QTL enhancing the resistance were mapped [43]. Among the QTL identified for resistance to $\mathrm{FHB}$, only seven have been formally designated, i.e., $F h b 1$ derived from Sumai 3 [15], Fhb2 from Sumai 3 [14], Fhb3 from Leymus racemosus [51], Fhb4 from Wangshuibai [64], Fhb5 from Wangshuibai and Sumai 3 [65], Fhb6 from Elymus tsukushiensis [8], and Fhb7 from Thinopyrum ponticum [27]. Recent investigations of several other wild relatives of wheat, such as diploid wheatgrass
Leymus racemosus, Th. intermedium, and tetraploid wheatgrass Th. junceiforme, have been shown to be highly resistant to FHB $[5,11,16,37]$. Additionally, some wheatwild species, including accessions of the St genome of Th. intermedium and the E genome of Th. elongatum, have been shown highly resistant to FHB, making these species the most successful examples for introgression of elite genes from wild relatives for wheat improvement [32, 54, 67]. Using sequence information obtained from the cloned gene, Rawat et al. [52] studied the origin of $F h b 1$ in wheat and related species, and sequenced $F h b 1$ gene from a large set of diploid A- genome, S- genome and $\mathrm{D}$ - genome accessions. Using sequence data from $T h$. elongatum, Wang et al. [62] mapped Fhb7 and located it to a $245-\mathrm{kb}$ genomic region. Thus, $F h b 7$ resistance differs from $F h b 1$ resistance, which depends on a reduction of pathogen growth in spikes, although both confer durable resistance.

Wheat-Thinopyrum partial amphiploids play an important role in the transfer of disease-resistant genes from wheatgrass species into common wheat $[39,41]$. To date, a number of wheat-Th. intermedium partial amphiploids have been developed, such as Zhong 1 to Zhong 5 [56], Otrastsyuskaya (OT), TE-3, TAI8335 [21, 28, 66], TE253 and TE257 [4]. The present study focused on the development of five wheat-Th. intermedium partial amphiploids by crossing octoploid tritelytrigia $(2 n=8 \times=56$, AABBDDEE) with $T$. intermedium and characterized their FHB resistance and genomic constitutions by means of genomic in situ hybridization (GISH) and multicolor fluorescence in situ hybridization (mcFISH).

\section{Results}

\section{GISH and mcFISH analysis}

Chromosome counts indicated that lines HS2-2, HS2-4, and HS2-5 had 56 chromosomes, and lines HS2-14 and HS2-16 had 54 chromosomes (Table 1). GISH analysis using Th. intermedium genomic DNA as a probe and common wheat genomic DNA as a blocker revealed that

Table 1 Chromosome compositions of the wheat-Th. intermedium lines

\begin{tabular}{|c|c|c|c|c|c|}
\hline \multirow[t]{2}{*}{ Line } & \multirow[t]{2}{*}{ Pedigree } & \multirow[t]{2}{*}{$2 n=$} & \multirow[t]{2}{*}{$\begin{array}{l}\text { No. of wheat } \\
\text { chromosomes }\end{array}$} & \multicolumn{2}{|c|}{$\begin{array}{l}\text { No. of Th. intermedium } \\
\text { chromosomes }\end{array}$} \\
\hline & & & & J genome & $\begin{array}{l}\text { St or } J^{s} \\
\text { genome }\end{array}$ \\
\hline HS2-2 & Ganmai8/Th. intermedium & 56 & 42 & 10 & 4 \\
\hline $\mathrm{HS} 2-4$ & Ganmai8/Th. intermedium & 56 & 42 & 10 & 4 \\
\hline HS2-5 & Ganmai8/Th. intermedium & 56 & 42 & 14 & 0 \\
\hline HS2-14 & Ganmai8/Th. intermedium & 54 & 42 & 12 & 0 \\
\hline HS2-16 & Ganmai8/Th. intermedium & 54 & 42 & 12 & 0 \\
\hline
\end{tabular}


lines HS2-2, HS2-4, and HS2-5 had 14 Th. intermedium chromosomes and 42 wheat chromosomes. Lines HS2-14 and HS2-16 had 12 Th. intermedium chromosomes and 42 wheat chromosomes. In order to further distinguish the composition of them, both J-genomic DNA from Th. bessarabicum and multiplex oligo probes were used with common wheat Chinese Spring as a blocker in the in situ hybridization analysis. Based on the signal patterns and signal density produced by each oligo, A and D genome signals are red or green dot at the arm and terminal of chromosome, B genome centromere usually appears a lot of green dot, so we can distinguish wheat genomes [20, 61].

GISH analysis of line HS2-2 revealed that 10 chromosomes from Th. intermedium displayed a light-green fluorescence signals over most of their lengths except for the terminal and centromeric regions with the J-genome signals (Fig. 1a), and four chromosomes with no signals of J-genome and oligo-probes were $\mathrm{St}$ - or $\mathrm{J}^{\mathrm{S}}$-genome chromosomes from Th. intermedium (Fig. 1b). Line HS2-4 with the similar probe pattern of HS2-2 also had 10 chromosomes from Th. intermedium with light-green fluorescence signals as the J-genome (Fig. 1c), and four chromosomes with no signals of J-genome and oligoprobes were St- or $\mathrm{J}^{\mathrm{S}}$-genome chromosomes from $\mathrm{Th}$. intermedium (Fig. 1d). Line HS2-5 had 14 J chromosomes from Th. intermedium with the light-green J-genome signals (Fig. 1e). Line HS2-14 and HS2-16 had 12 chromosomes from Th. intermedium and some chromosomes with the whole light-green J-genome signals (Fig. 2a, c). Analysis of mcFISH with the oligo-probes demonstrated that all the lines maintained the complete set of wheat chromosomes from the A, B, and D genomes (Figs. 1b, d, f, 2b, d).

The above results revealed that line HS2-2 and HS2-4 with $2 \mathrm{n}=8 \times=56$ had 4 chromosomes of St- or $\mathrm{J}^{\mathrm{S}}$-genome chromosomes and $10 \mathrm{~J}$-genome chromosomes from Th. intermedium and 42 wheat chromosomes. The genome composition of line HS2-5 was 42 wheat chromosomes plus $14 \mathrm{~J}$-genome chromosomes from Th. intermedium. Lines HS2-14 and HS2-16 had 12 J-genome chromosomes from Th. intermedium and 42 wheat chromosomes. Therefore, these lines are identified as the wheat-Th. intermedium partial amphiploids.

\section{Morphological characteristics and seed protein contents}

In 2016 and 2017, results of morphological characteristics in the field are shown in Table 2. The average plant heights of lines HS2-2, HS2-4, and HS2-5 were lower than both parents, Ganmai 8 and Th. intermedium, but those of lines HS2-14 and HS2-16 were similar to their parents. Spike lengths of five lines were similar to the parent Ganmai 8. The number of tillers of the five lines was significantly less than that of the parent Th. intermedium, but similar to Ganmai 8 except for line HS2-14. Spikelet numbers per spike of the five lines were similar to the parent of Ganmai 8. Seeds of the main spikes from lines HS2-2 and HS2-4 were not significantly different from Ganmai 8, but higher than Th. intermedium. All lines had lower 1,000-kernal weight than Ganmai 8, but higher than Th. intermedium. Seed color of the five lines was red (Fig. 3). All the lines were resistant to lodging. Maturity of line HS2-14 and HS2-16 was similar to the local spring wheat cultivar Longmai 33. However, maturity of lines HS2-2, HS2-4, and HS2-5 was later than that of Longmai 33. Seed protein content of the five lines (18.3\%-22.5\%) was higher than that of the parent Ganmai 8 (18.1\%), but lower than Th. intermedium (26.0\%). Lines HS2-2, HS2-4, HS2-5, and HS2-14 had more than 19\% protein content and lines HS2-2 and HS2-5 had the highest values of up to $22.5 \%$ and $20.7 \%$, respectively (Table 2 ).

\section{FHB resistance evaluation}

In 2016 and 2017, the five partial amphiploids were tested for their FHB resistance in the field. In resistant plants, the fungal infection was restricted to the central inoculated spikelets and did not spread up or down across the spikes (Fig. 3). The field evaluation performed in both 2016 and 2017 showed that all the five lines exhibited better resistance to FHB than the susceptible control Longmai 33 and the resistant control Sumai 3. Values of PSS for lines HS 2-2, HS2-4, HS2-5, and HS2-16 were less than 20\% (Table 3). Line HS2-5 showed the best resistance, with the PSS values of $11 \%$ and $17 \%$ in both 2016 and 2017. Line HS2-2 had a better FHB resistance with the PSS values of $15 \%$ and $18 \%$ during 2016 and 2017. The values of PSS for lines 2-4 and HS2-16 were $18 \%$ and $20 \%, 16 \%$ and $19 \%$ in the two years, respectively. In contrast, line HS2-14 had the PSS values of $30 \%$ and $28 \%$ during 2016 and 2017 (Table 3).

\section{Discussion}

The production of partial amphiploids is a crucial intermediate step in transferring desirable genes from wheatgrass to wheat [22, 35]. Several wheat-Th. intermedium partial amphiploids have been developed and widely exploited as sources of disease resistance in wheat improvement [3, 4, 57, 68]. Georgieva et al. [25] obtained two intergeneric wheat/wheatgrass amphiploid lines H95 and 55(1-57) with high protein content and resistance to certain fungal diseases. Breeding for FHB resistance is difficult because it is a complex trait controlled by multiple genes and influenced by environments $[9,26,36,52$, 53]. Jauhar and Peterson [33] attempted to transfer FHB resistance of diploid Th. elongatum into durum wheat. After screening a series of wheat-Th. elongatum derived lines for FHB resistance, Fu et al. [24] indicated that the 


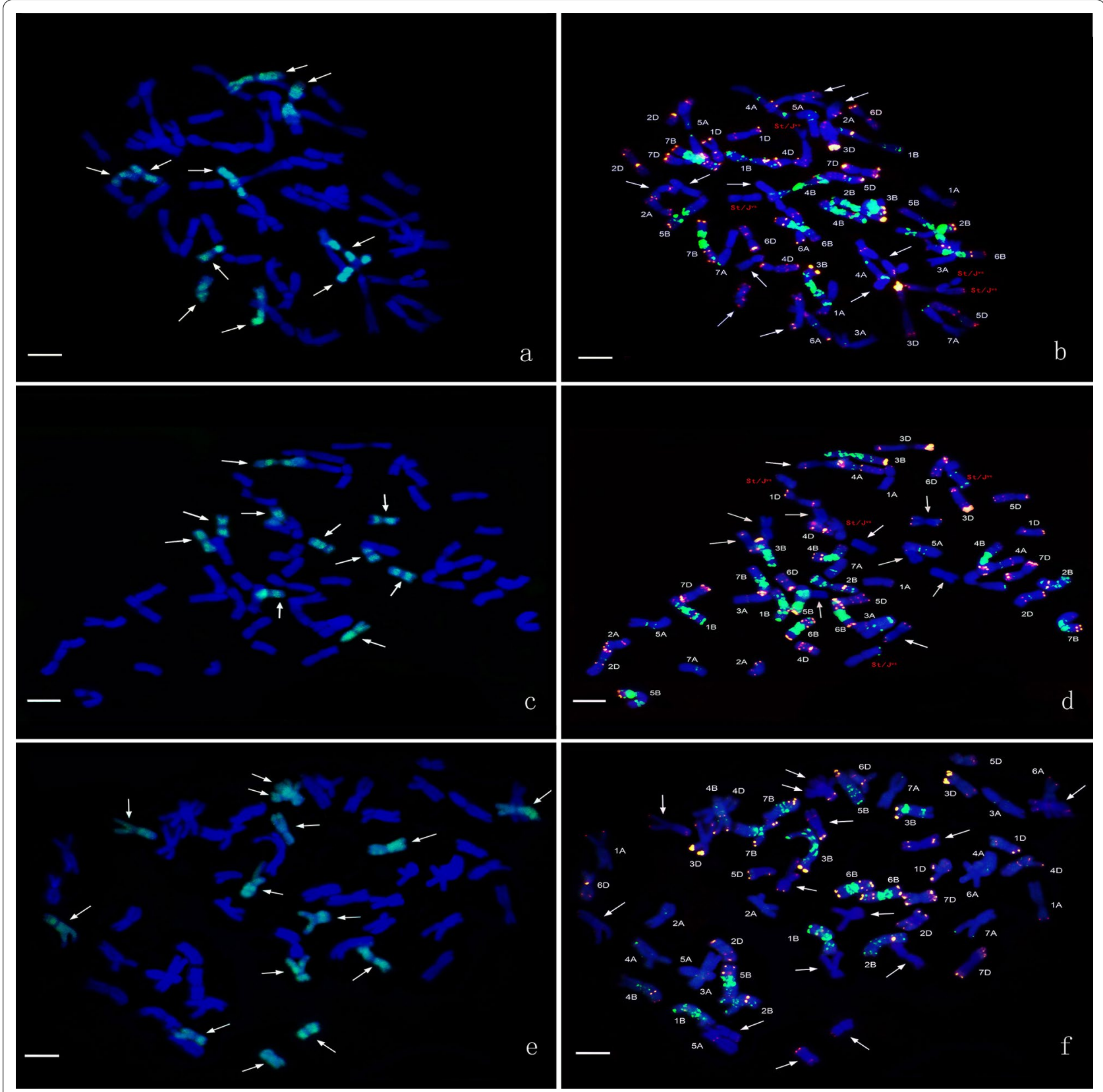

Fig. 1 GISH and mcFISH patterns from lines HS2-2, HS2-4 and HS2-5. a, c, e Th. bessarabicum (J) genomic DNA labeled with fluorescein-12-dUTP was used as a probe for green signals, and common wheat cultivar Chinese Spring as a blocker. b, d, f The synthetic oligo pAs 1-1, pAs 1-3, and AFA-4 were $5^{\prime}$ end-labelled with 6-carboxytetramethyl-rhodamine (TAMRA) for red signals. The synthetic oligo pSc119.2-1 and (GAA) 10 were 5' end-labelled with 6-carboxyfluorescein (6-FAM) for green signals. White arrows show the J-genome chromosomes. Bar= $10 \mu \mathrm{m}$. $\mathbf{a}, \mathbf{b}$ line HS2-2, $\mathbf{c}, \mathbf{d}$ : line HS2-4, e, f line HS2-5

short arm of chromosome 7E of Th. elongatum conferred a high level of resistance to the spread of FHB. The resistance genes from Th. ponticum can be pyramided with the currently identified resistance genes in wheat to enhance the genetic diversity and provide more durable resistance of wheat to FHB. Liu et al. [47] reported three common
wheat-Th. ponticum derived cultivars Xinong 509, Xinong 511 and Xinong 529 with good FHB resistance, which carry a chromosome 7E segment of the decaploid Th. ponticum. Four FHB resistant wheat lines L658, L693, L696, and L699 were developed [48], which demonstrates 


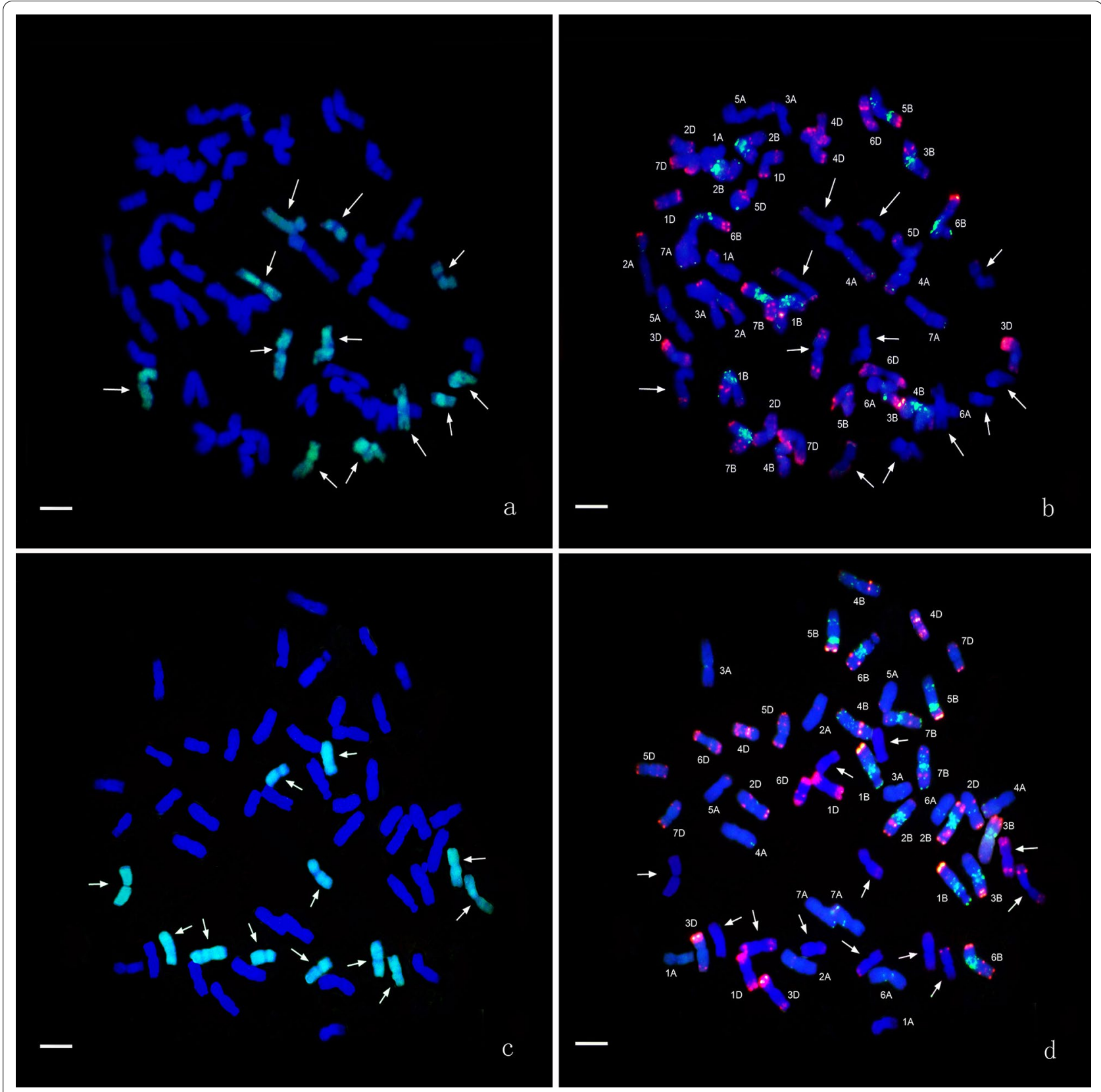

Fig. 2 GISH and mcFISH patterns from lines HS2-14 and HS2-16. a, c: Th. bessarabicum (J) genomic DNA labeled with fluorescein-12-dUTP was used as a probe for green signals, and common wheat cultivar Chinese Spring as a blocker. b. d: The synthetic oligo pAs 1-1, pAs 1-3, and AFA-4 were 5' end-labelled with 6-carboxytetramethyl-rhodamine (TAMRA) for red signals. The synthetic oligo pSc119.2-1 and (GAA) 10 were 5' end-labelled with 6-carboxyfluorescein (6-FAM) for green signals. White arrows show the J-genome chromosomes. Bar= 10 um. $\mathbf{a}$, b: line HS 2-14, c, d: line HS 2-16

the possibility of using Th. intermedium to develop novel wheat germplasm with different disease resistance.

In this study, five wheat-Th. intermedium partial amphiploids derived from the octoploid tritelytrigia $(2 \mathrm{n}=8 \times=56$, AABBDDEE) and Th. intermedium showed the resistance to FHB. GISH and mcFISH results revealed that these lines had 10-14 J-genome chromosomes from Th. intermedium. Line HS2-5 had the best resistance to FHB, which indicated that certain J-genome chromosomes of Th. intermedium harbored genes for FHB resistance. Chen et al. [12] reported that T. durum $\times$ Th. distichum hybrid lines, AFR4 and AFR5, expressed a significantly higher level of resistance to the spread of FHB compared to the other durum wheat-alien 
Table 2 The morphological characters for the five wheat-Th. intermedium lines, contrals and their parents in 2017

\begin{tabular}{|c|c|c|c|c|c|c|c|c|}
\hline Line & $\begin{array}{l}\text { Plant } \\
\text { height }(\mathrm{cm})\end{array}$ & Spike length $(\mathrm{cm})$ & Tiller & $\begin{array}{l}\text { Spikelet } \\
\text { number }\end{array}$ & $\begin{array}{l}\text { Seeds } \\
\text { of main spike }\end{array}$ & $\begin{array}{l}\text { 1000-kernal } \\
\text { weigh (g) }\end{array}$ & $\begin{array}{l}\text { Seed protein } \\
\text { content (\%) }\end{array}$ & Maturity \\
\hline Longmai33 & $95^{\mathrm{a}}$ & $11.2^{\mathrm{ef}}$ & $4^{b}$ & $19^{\mathrm{a}}$ & $46^{b}$ & $41^{\mathrm{ab}}$ & $17.3^{c}$ & $92^{\mathrm{bc}}$ \\
\hline Sumai3 & $82^{b}$ & $8.5^{f}$ & $5^{b}$ & $16^{\mathrm{a}}$ & $48^{a}$ & $34.5^{b}$ & $15.2^{c}$ & $80^{c}$ \\
\hline Ganmai 8 & $97^{\mathrm{a}}$ & $13.8^{c}$ & $4^{b}$ & $18^{\mathrm{a}}$ & $46^{b}$ & $36.3^{b}$ & $18.1^{c}$ & $95^{b}$ \\
\hline Th. intermedium & $82^{b}$ & $27.4^{\mathrm{ab}}$ & $65^{\mathrm{ab}}$ & $20^{\mathrm{a}}$ & $25^{d}$ & $8.2^{c}$ & $26.0^{\mathrm{ab}}$ & $110^{\mathrm{ab}}$ \\
\hline $\mathrm{HS} 2-2$ & $75^{b}$ & $14.5^{b c}$ & $4^{b}$ & $18^{\mathrm{a}}$ & $46^{b}$ & $30.4^{b}$ & $22.5^{\mathrm{b}}$ & $112^{\mathrm{a}}$ \\
\hline $\mathrm{HS} 2-4$ & $78^{b}$ & $13.5^{c}$ & $3^{b}$ & $18^{\mathrm{a}}$ & $44^{\mathrm{bc}}$ & $31.4^{b}$ & $20.0^{\mathrm{b}}$ & $112^{\mathrm{a}}$ \\
\hline HS2-5 & $80^{b}$ & $13.2^{c}$ & $3^{b}$ & $17^{a}$ & $29^{c d}$ & $29.2^{b c}$ & $20.7^{b}$ & $112^{\mathrm{a}}$ \\
\hline HS2-14 & $92^{\mathrm{ab}}$ & $12.7^{\mathrm{de}}$ & $7^{b}$ & $15^{\mathrm{a}}$ & $35^{c}$ & $32.2^{b}$ & $19.6^{b}$ & $95^{\mathrm{b}}$ \\
\hline HS2-16 & $93^{\mathrm{a}}$ & $13.1^{\mathrm{cd}}$ & $5^{b}$ & $14^{\mathrm{a}}$ & $32^{c}$ & $33.3^{b}$ & $18.3^{\mathrm{bc}}$ & $95^{\mathrm{b}}$ \\
\hline
\end{tabular}

All indices are described by mean; means in a column followed by the same letter(s) are not significantly different at a $5 \%$ probability level

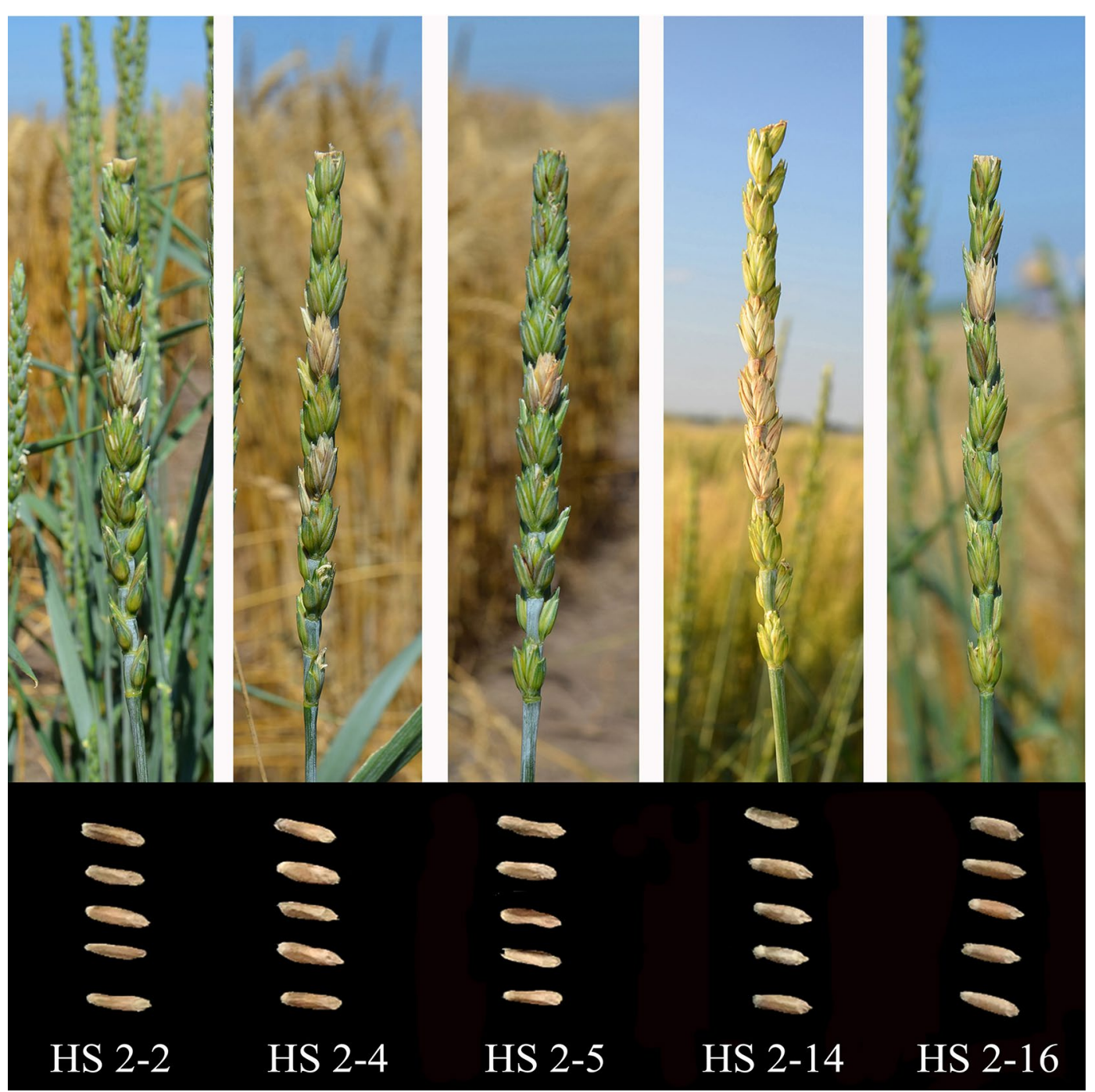

Fig. 3 Evaluation of Fusarium head blight resistance and seed morphologies of five wheat-Th. intermedium partial amphiploids. The above is the FHB test results in the field (photo taken in July 2017). The below is harvested seeds (photo taken in August 2017). From left to right, lines HS2-2, HS2-4, HS2-5, HS2-14, and HS2-16 
Table 3 The evaluation of Fusarium head blight resistance in 2016 and 2017

\begin{tabular}{llllll}
\hline Line & \multicolumn{2}{l}{$\mathbf{2 0 1 6}$} & & \multicolumn{2}{l}{$\mathbf{2 0 1 7}$} \\
\cline { 2 - 3 } \cline { 5 - 6 } & $\mathbf{N}$ & PSS & & $\mathbf{N}$ & PSS \\
\hline Longmai 33 (S) & 30 & $0.82 \pm 0.02^{\mathrm{b}}$ & & 30 & $0.85 \pm 0.02^{\mathrm{b}}$ \\
Sumai 3(R) & 30 & $0.30 \pm 0.01^{\mathrm{b}}$ & & 30 & $0.31 \pm 0.02^{\mathrm{b}}$ \\
HS2-2 & 30 & $0.15 \pm 0.02^{\mathrm{b}}$ & & 30 & $0.18 \pm 0.03^{\mathrm{b}}$ \\
HS2-4 & 30 & $0.18 \pm 0.02^{\mathrm{b}}$ & & 30 & $0.20 \pm 0.02^{\mathrm{ab}}$ \\
HS2-5 & 30 & $0.11 \pm 0.01^{\mathrm{b}}$ & & 30 & $0.17 \pm 0.04^{\mathrm{b}}$ \\
HS2-14 & 30 & $0.30 \pm 0.03^{\mathrm{a}}$ & & 30 & $0.28 \pm 0.03^{\mathrm{a}}$ \\
HS2-16 & 30 & $0.16 \pm 0.03^{\mathrm{b}}$ & & 30 & $0.19 \pm 0.03^{\mathrm{b}}$ \\
\hline
\end{tabular}

All indices are described by mean \pm standard error

Means in a column followed by the same letters are not significantly different at $P<0.05$

$N$ number of plant spikes, PSS the percent of symptomatic spikelets

hybrid lines. GISH analysis revealed that all of the alien chromosomes present in lines AFR4 and AFR5 belong to the J-genome. Therefore, Th. bessarabicum and Th. intermedium as the donor for J-genome chromosomes can be used for breeding FHB resistance. In addition, lines HS2-2 and HS2-5 had not only the least PSS value, but also higher seed protein content (22.5\% and $20.7 \%)$, indicating that these wheat-Th. intermedium amphiploids are considered both as a "breeding bridge" in the transfer of genes from the intermedium wheatgrass to common wheat.

Th. intermedium, as an allohexaploid species, is proposed to be formed by an ancient hybridization event between the diploid Pseudoroegneria strigosa $(2 \mathrm{n}=2 \times=14, \mathrm{StSt})$ and a segmental tetraploid carrying $\mathrm{J}^{\mathrm{r}}$ and $\mathrm{J}^{\mathrm{vs}}$ genomes [13]. The $\mathrm{J}^{\mathrm{r}}$ and $\mathrm{J}^{\mathrm{vs}}$ genomes represent ancestral genomes of the present $\mathrm{J}^{\mathrm{b}}$ genome of $T h$. bessarabicum and the $\mathrm{J}^{\mathrm{e}}$ genome of Th. elongatum respectively [58]. The $\mathrm{J}^{\mathrm{vs}}$ genome is distinct from the $\mathrm{J}^{\mathrm{b}}$ genome as it retains the repetitive sequences from the $\mathrm{V}$ genome of Dasypyrum villosum L. Candagy [13]. These genomes provide abundant genetic resources for their hybrid progenies.

Identification and tracking of these chromosomes is a prerequisite for directed chromosome engineering. The technologies of GISH and FISH can be used to differentiate and localize Th. intermedium, Th. ponticum, and Th. elongatum chromosomes in wheat backgrounds [63]. In this study, the multiplex oligos containing probe combined with the J-genome DNA as probe were used to discriminate chromosomes from $T h$. intermedium in wheat backgrounds. The J-genome chromosome signals of the five partial amphiploids lines showed two types of hybrid signals. One displayed a light-green fluorescence signals over most of their lengths except for the terminal and centromeric regions as detected by the J-genome probe, such as lines HS2-2, HS2-4 and HS2-5 (Fig. 1a, c, e). This type of hybrid signals was identified by Cseh et al. [13] with the genomic DNA as the probes from the diploid Ps. strigosa (St) and Th. bessarabicum (J). Another type of signals covered the entire chromosome with a whole light-green fluorescence signal, such as part of J-genome chromosomes of line HS2-16 (Fig. 2c). Two types of hybridization signal on the J-genome chromosomes indicated that among the five partial amphiploid lines developed, the characteristics of these J-genome chromosomes from Th. intermedium were not exactly the same as Th. bessarabicum. In addition, compared with the conventional FISH probe, synthesized oligonucleotide probe has the advantages of low cost, high sensitivity and high resolution [20]. In this study, although oligo probes were used to distinguish wheat genome, there were some specific signals on J-genome chromosome (Figs. 1, 2), which indicated that the further development of oligo probes on J-genome chromosome would help to improve the recognition efficiency of J-genome chromosome.

\section{Conclusions}

Five wheat-Th. intermedium partial amphiploids with FHB resistance and good protein contents were developed by crossing octoploid tritelytrigia $(2 n=8 \times=56$, AABBDDEE) with Th. intermedium. Their genomic constitutions was examined by means of GISH and multicolor-FISH. These wheat-Th. intermedium amphiploids with the J-genome chromosomes from Th. intermedium were identified and can be considered as a valuable source of FHB resistance in wheat breeding.

\section{Methods \\ Plant materials}

The plant materials used in this study included Th. intermedium, Th. bessarabicum, five lines of partial amphiploids and common wheat, Chinese Spring (CS). Th. intermedium $\left(2 \mathrm{n}=6 \times=42 \quad \mathrm{StSt} J J J^{\mathrm{S}} \mathrm{J}^{\mathrm{S}}\right)$, Longmai 33 $(2 \mathrm{n}=6 \times=42$ AABBDD $)$ and Sumai $3(2 \mathrm{n}=6 \times=42$ AABBDD) were obtained from the Heilongjiang Academy of Agricultural Sciences, Harbin, China. Thinopyrum bessarabicum $\left(2 n=2 \times=14 \mathrm{JJ}\right.$ or $\left.\mathrm{J}^{\mathrm{b}} \mathrm{J}^{\mathrm{b}}\right)$ was kindly supplied by Dr. Zengjun Qi, Nanjing Agricultural University, Nanjing, Jiangsu province, China. The lines of wheat-Th. intermedium partial amphiploids, HS2-2, HS24, HS2-5, HS2-14, and HS2-16, were developed from crosses between Ganmai 8 and Th. intermedium at the College of Life Science and Technology of Harbin Normal University, Harbin, Heilongjiang province, China. Ganmai 8 is an octoploid tritelytrigia partial amphiploids (AABBDDEE, $2 n=8 \times=56$ ) that were developed from the cross between common wheat line $91 \mathrm{C}-9$ and 
the partial amphiploid line Yuan 16-3 $(2 n=8 x=56$, AABBDDEE) in Shanxi Academy of Agricultural Sciences, Taiyuan, Shanxi province, China. Chinese Spring wheat $(2 \mathrm{n}=6 \times=42$, AABBDD) were provided by the College of Life Science and Technology of Harbin Normal University.

\section{FHB assessments}

The experiment was conducted over two years in two fields: Minzhu field at Crop Resources Institute, Hongjiang Academy of Agriculture Sciences $\left(126^{\circ} 27^{\prime} \mathrm{E}\right.$ and 51 $16.12^{\prime} \mathrm{N}$ ), Harbin, China, in 2016 and 2017; field at Harbin Normal University $\left(126^{\circ} 57^{\prime} \mathrm{E}\right.$ and $\left.45^{\circ} 87^{\prime} \mathrm{N}\right)$, China, in 2016 and 2017. We used a randomized complete block to design an experiment with three replications. The plot consisted of $2.0-\mathrm{m}$ long rows, and the space between rows was $0.4 \mathrm{~m}$. To determine FHB resistance, the field spikelet-cutting method was used to inoculate. Ten microliter of a macroconidial suspension (5000 macroconidia per $\mathrm{ml}$ ) of the spore-derived isolate of F. graminearum No. 4 (provided by Plant Protection Institute, Honglongjiang Academy of Agriculture Sciences, Harbin, China) was injected into 10 random selected plants spikes at early anthesis each. The inoculated spikes were covered with plastic bags for $3 \mathrm{~d}$ to maintain the relative humidity and temperature. The data was recorded at $21 \mathrm{~d}$ after inoculation. The number of symptomatic spikelets and the total number of spikelets of every tagged spike were counted for the percent of symptomatic spikelets (PSS). Longmai 33 served as the susceptible controls and Sumai 3 served as the resistant control in both fields.

\section{Morphological observation and protein content of measurement}

During 2016 and 2017, each lines was grown in plots consisting of $2.0-\mathrm{m}$ long rows, and spaced $0.4 \mathrm{~m}$ that were arranged in a randomized complete block design with three replicates in two fields. Thirty seeds were sown in a row in early April and harvested at end of July. The agronomic performances were investigated in two consecutive years in two fields. From each line, plant height $(\mathrm{cm})$, spike length $(\mathrm{cm})$, number of spikelets per spike, 1000-kernal weigh, awn, and maturity date were recorded in ten randomly sampled individuals from each plot during the growing seasons. Morphological observations were carried out as described previously [42]. Plant height was determined from the ground level to the top of the spike, and spike length was measured from the base of rachis to the top of the spike. In addition, number of spikelets per spike was enumerated and the spikes were threshed in a bench micro-thresher to determine thousand-kernel weight $(\mathrm{g})$. One hundred seeds of each line with the same seed shape were placed into the sample cup. DA7200 Multifunctional Near Infrared Spectromete (Perten, Switzerland) was used for testing the protein content of seed and recorded the data. Simplicity software for data analysis.

\section{Chromosome preparation}

Seeds were germinated at $23.5^{\circ} \mathrm{C}$ for $24 \mathrm{~h}$ in moist filter paper in Petri dishes, incubated at $4{ }^{\circ} \mathrm{C}$ for $48 \mathrm{~h}$, and then returned to $23.5^{\circ} \mathrm{C}$ for $27.5 \mathrm{~h}$. Root tips were treated with ice water at $0-4{ }^{\circ} \mathrm{C}$ for $24 \mathrm{~h}$, fixed in Carnoy's fixative (Anhydrous alcohol: Acetic acid=3:1) for $24 \mathrm{~h}$, and stained in $1 \%$ acetic carmine for at least $5 \mathrm{~h}$. Root tips were squashed in $45 \%$ acetic acid and observed under a light microscope (BH-2, Olympus, Tokyo, Japan).

\section{In situ hybridization}

Genomic DNA was isolated using a CTAB method [19] from young leaves of the three putative diploid progenitors Th. bessarabicum and labeled with fluorescein12-dUTP by the nick translation method to be used as the probes. Sheared genomic DNA from Chinese Spring (AABBDD, $2 \mathrm{n}=42$ ) was used as the blocking DNA. The protocols of GISH and multicolor FISH using the synthesized probes were described by Wang et al. [61]. An oligonucleotide (oligo hereafter) multiplex containing oligos pAs1-1, pAs1-3, AFA-4, (GAA) 10, and pSc119.21 , was used for identifying $A, B$ and $D$ genomes of wheat that was previously described by Wang et al. [61] and Du et al. [20]. The oligo probes were synthesized by TsingKe biotechnology Co. Ltd. (Beijing, China). The synthetic oligo $p A s 1-1, p A s 1-3$, and AFA-4 were $5^{\prime}$ end-labelled with 6-carboxytetramethyl-rhodamine (TAMRA) for red signals. The synthetic oligo $p S c 119.2-1$ and (GAA ) 10 were $5^{\prime}$ end-labelled with 6-carboxyfluorescein (6-FAM) for green signals. Hybridization stringency $(\%)=100+$ hybridization temperature $\left(\mathrm{T}_{\mathrm{h}}\right)$ - melting temperature $\left(\mathrm{T}_{\mathrm{m}}\right)=100+37{ }^{\circ} \mathrm{C}\left(\mathrm{T}_{\mathrm{h}}\right)-105{ }^{\circ} \mathrm{C}\left(\mathrm{T}_{\mathrm{m}}\right)=32 \%$. Photographs were captured with a Leica DM6000B fluorescence microscope (Leica, Mannheim, Germany) equipped with a digital camera (Leica model DFC480).

\section{Statistical analysis}

Significant differences in the means of different genotypes for PSS were determined by the multiple samples $t$-test at $P<0.05$ using IBM SPSS Statistics 19 software (SPSS Inc., Chicago, IL), and the significance of differences in the same genotype indices between inoculated and non-inoculated plants was also determined by the independent samples $t$-test at $P<0.05$ with the same software. 


\section{Abbreviations}

GISH: genomic in situ hybridization; FISH: fluorescence in situ hybridization; mcFISH: multicolor fluorescence in situ hybridization; PSS: percent of symptomatic spikelets; FHB: fusarium head blight.

\section{Acknowledgements}

We thank Dr. Zengjun Qi, Nanjing Agricultural University, Nanjing, China, for technical assistance of the oligonucleotide multiplex-based chromosome painting. We also thank Dr. Hongije Li, Institute of Crop Science, Chinese Academy of Agricultural Sciences, Beijing, China, for his carefully and patiently revising the paper and giving constructive suggestions.

\section{Authors' contributions}

$Y Z$ and $X L$ conceived the project. HW and WY conducted the experiments and drafted the manuscript. SC, YS, SZ and QS performed GISH experiments and phenotyped the FHB. WS, XY, and SZ assisted in the oligo-FISH experiments. $\mathrm{BF}$ and $\mathrm{YZ}$ reviewed the manuscript. All authors reviewed and approved the manuscript.

\section{Funding}

This research was financially supported by The National Key Research and Development Program of China (2016YFD0100102) and Innovation Project of Master's Degree in Harbin Normal University (HSDSSCX2019-16).

\section{Availability of data and materials}

All data generated or analyzed during this study are included in this published article.

\section{Ethics approval and consent to participate}

Not applicable.

\section{Consent for publication}

Written informed consent for publication was obtained from all participants.

\section{Competing interests}

The authors declare that they have no conflicts of interest.

\section{Author details}

${ }^{1}$ Key Laboratory of Molecular Cytogenetics and Genetic Breeding of Heilongjiang Province, College of Life Science and Technology, Harbin Normal University, Harbin 150025, China. ${ }^{2}$ Crop Resources Institute, Heilongjiang Academy of Agriculture Sciences, Harbin 150086, China. ${ }^{3}$ Department of Plant Pathology, Wheat Genetics Resource Center, Throckmorton Plant Sciences Center, Kansas State University, Manhattan, KS 66506-5502, USA.

\section{Received: 9 December 2020 Accepted: 19 February 2021}

\section{Published online: 06 March 2021}

\section{References}

1. Anderson JA, Stack W, Liu S, Waldron BL, Fjeld AD, Coyne C, MorenoSevilla B, Fetch J, Song QJ, Cregan PB, Frohberg RC. DNA markers for Fusarium head blight resistance QTLs in two wheat populations. Theor Appl Genet. 2001;102(8):1164-8. https://doi.org/10.1007/s001220000509.

2. Bai G, Shaner $G$. Management and resistance in wheat and barley to Fusarium head blight. Annu Rev Phytopathol. 2004;42(1):135-61. https:// doi.org/10.1146/annurev.phyto.42.040803.140340.

3. Bao Y, Li X, Liu S, Cui F, Wang H. Molecular cytogenetic characterization of a new wheat-Thinopyrum intermedium partial amphiploid resistant to powdery mildew and stripe rust. Cytogenet Genome Res. 2009;126:3905. https://doi.org/10.2290/ijms16012162.

4. Bao Y, Wu X, Zhang C, Li X, He F, Qi X, Wang H. Chromosomal constitutions and reactions to powdery mildew and stripe rust of four novel wheat-Thinopyrum intermedium partial amphiploids. J Genet Genomics. 2014;41(12):663-6. https://doi.org/10.1016/j.jgg.2014.11.003.

5. Becher R, Miedaner T, Wirsel SGR. Biology, diversity, and management of FHB-causing Fusarium species in small-grain cereals. In: Kempken F (ed) Agricultural applications, vol. 11. Springer, Berlin. 2013; pp 199-241. https ://doi.org/10.1007/978-3-642-36821-9_8
6. Brar GS, Brûlé-Babel AL, Ruan Y, Henriquez MA, Pozniak CJ, Kutcher $\mathrm{HR}$, HuCl PJ. Genetic factors affecting Fusarium head blight resistance improvement from introgression of exotic Sumai 3 alleles (including Fhb1, Fhb2, and Fhb5) in hard red spring wheat. BMC Plant Biol. 2019;19(1):179. https://doi.org/10.1186/s12870-019-1782-2.

7. Buerstmayr H, Ban T, Anderson JA. QTL mapping and marker-assisted selection for Fusarium head blight resistance in wheat: a review. Plant Breed. 2010;128(1):1-26. https://doi.org/10.1111/j.1439-0523.2008.01550 .x.

8. Cainong JC, Bockus WW, Feng Y, Chen P, Qi L, Sehgal SK, Danilova TV, Koo DH, Friebe B, Gill BS. Chromosome engineering, mapping, and transferring of resistance to Fusarium head blight disease from Elymus tsukushiensis into wheat. Theor Appl Genet. 2015;128(6):1-9. https://doi. org/10.1007/s00122-015-2485-1.

9. Ceoloni C, Forte P, Kuzmanović L, Moscetti I, De Vita P, Virili ME, D'Ovidio R. Cytogenetic mapping of a major locus for resistance to fusarium head blight and crown rot of wheat on Thinopyrum elongatum 7EL and its pyramiding with valuable genes from a Th. ponticum homoeologous arm onto bread wheat 7DL. Theor Appl Genet. 2017. https://doi.org/10.1007/ s00122-017-2939-8.

10. Chang ZJ, Zhang XJ, Yang ZJ, Zhan HX, Li X, Liu C, Zhang CZ. Characterization of a partial wheat-Thinopyrum intermedium amphiploid and its reaction to fungal diseases of wheat. Hereditas. 2011;147(6):304-12. https ://doi.org/10.1111/j.1601-5223.2010.02156.x.

11. Chen P, Liu W, Yuan J, Wang X, Zhou B, Wang S, Zhang S, Feng Y, Yang B, Liu G, Liu D, Qi L, Zhang P, Friebe B, Gill BS. Development and characterization of wheat-Leymus racemosus translocation lines with resistance to Fusarium head blight. Theor Appl Genet. 2005;111(5):941-8. https://doi. org/10.1007/s00122-005-0026-z.

12. Chen Q, Eudes F, Conner RL, GrafR, Comeau A, Collin J, Ahmad F, Zhou R, $\mathrm{Li} \mathrm{H}$, Zhao Y, Laroche A. Molecular cytogenetic analysis of a durum wheat $\times$ Thinopyrum distichum hybrid used as a new source of resistance to Fusarium head blight in the greenhouse. Plant Breed. 2010;120(5):375-80. https://doi.org/10.1046/j.1439-0523.2001.00630.x.

13. Cseh A, Yang C, Hubbart-Edwards S, Scholefeld D, Ashling SS, Burridge AJ, Wilkinson PA, King PI, King J, Grewal S. Development and validation of an exome-based SNP marker set for identification of the genomes St, Jr and Js of Thinopyrum intermedium in a wheat background. Theor Appl Genet. 2019;132(5):1-16. https://doi.org/10.1007/s00122-019-03300-9.

14. Cuthbert PA, Somers DJ, Brulé-Babel A. Mapping of Fhb2 on chromosome 6BS: a gene controlling Fusarium head blight field resistance in bread wheat (Triticum aestivum L.). Theor Appl Genet. 2007;114(3):429-37. https://doi.org/10.1007/s00122-006-0439-3.

15. Cuthbert PA, Somers DJ, Thomas J, Cloutier S, Brulé-Babel A. Fine mapping Fhb1, a major gene controlling fusarium head blight resistance in bread wheat (Tritium aestivum L.). Theor Appl Genet. 2006;112(8):1465-72. https://doi.org/10.1007/s00122-006-0249-7.

16. Dai Y, Duan Y, Liu H, Chi D, Cao W, Xue A, Gao Y, Fedak G, Chen J. Molecular cytogenetic characterization of two Triticum-Secale-Thinopyrum trigeneric hybrids exhibiting superior resistance to Fusarium head blight, leaf rust, and stem rust race Ug99. Front Plant Sci. 2017:8:797. https://doi. org/10.3389/fpls.2017.00797.

17. Danilova TV, Zhang G, Liu W, Friebe B. Homoeologous recombinationbased transfer and molecular cytogenetic mapping of a wheat streak mosaic virus and Triticum mosaic virus resistance gene $W s m 3$ from Thinopyrum intermedium to wheat. Theor Appl Genet. 2017;130:549-56. https://doi.org/10.1007/s00122-016-2834-8.

18. DeHaan L, Christians M, Crain J, Poland J. Development and evolution of an intermediate wheatgrass domestication program. Sustainability. 2018;10(5):1499. https://doi.org/10.3390/su10051499.

19. Doyle JJ, Doyle JL. A rapid DNA isolation procedure for small quantities of fresh leaf tissue. Phytochem Bull. 1987;19:11-5. https://doi.org/10.3390/ ijms140714860.

20. Du P, Zhuang L, Wang Y, Li Y, Wang Q, Wang D, Dawadondup X, Tan L, Shen J, Qi Z. Development of oligonucleotides and multiplex probes forquick and accurate identification of wheat and Thinopyrum bessarabicum chromosomes. Genome. 2017;60:93-103. https://doi.org/10.1139/ gen-2016-0095.

21. Fedak G, Chen Q, Conner RL, André L, Armstrong KW. Characterization of wheat-Thinopyrum partial amphiploids by meiotic analysis and genomic 
in situ hybridization. Genome. 2000;43(4):712-9. https://doi.org/10.1139/ g00-027.

22. Fedak G, Han F. Characterization of derivatives from wheat-Thinopyrum wide crosses. Cytogenet Genome Res. 2005;109(1-3):360-7. https://doi. org/10.1159/000082420.

23. Friebe B, Jiang J, Raupp WJ, Mcintosh RA, Gill BS. Characterization of wheat-alien translocations conferring resistance to diseases and pests: current status. Euphytica. 1996;91(1):59-87. https://doi.org/10.1007/bf000 35277.

24. Fu S, Lv Z, Qi B, Guo X, Li J, Liu B, Han F. Molecular cytogenetic characterization of wheat-Thinopyrum elongatum addition, substitution and translocation lines with a novel source of resistance to wheat Fusarium Head Blight. J Genet Genom. 2012;39:103-10.

25. Georgieva M, Adél S, Tyankova N, Molnár-Láng M. Molecular cytogenetic characterization of two high protein wheat-Thinopyrum intermediumpartial amphiploids. J Appl Genet. 2011;52:269-77. https://doi.org/10.1007/ s13353-011-0037-1.

26. Gilbert J, Haber S. Overview of some recent developments in fusarium head blight of wheat. Can J Plant Pathol. 2013;35:149-74. https://doi. org/10.1080/07060661.2013.772921.

27. Guo J, Zhang X, Hou Y, Cai J, Kong L. High-density mapping of the major $\mathrm{FHB}$ resistance gene $\mathrm{Fhb7}$ derived from Thinopyrum ponticum and its pyramiding with Fhb1 by marker-assisted selection. Theor Appl Genet. 2015;128:2301-16. https://doi.org/10.1007/s00122-015-2586-X.

28. Han F, Liu B, Fedak G, Liu Z. Genomic constitution and variation in five partial amphiploids of wheat-Thinopyrum intermedium as revealed by GISH, multicolor GISH and seed storage protein analysis. Theor Appl Genet. 2004;109:1070-6. https://doi.org/10.1007/s00122-004-1720-y.

29. Han FP, Fedak G, Benabdelmouna A, Armstrong K, Ouellet T. Characterization of six wheat $\times$ Thinopyrum intermedium derivatives by GISH, RFLP, and multicolor GISH. Genome. 2003:46:490-5. https://doi.org/10.1139/ g03-032.

30. He M, Xu Z, Zou M, Zhang H, Chen D, Pu Z, Hao S. The establishment of two sets of alien addition lines of wheatgrass. Sci China Ser B. 1989:6:57-67.

31. Hu L, Li G, Zeng Z, Chang Z, Liu C, Zhou J, Yang Z. Molecular cytogenetic identification of a new wheat-Thinopyrum substitution line with stripe rust resistance. Euphyrica. 2011;177:169-77. https://doi.org/10.1007/ s10681-010-0216-X.

32. Jauhar PP, Peterson TS, XU SS. Cytogenetic and molecular characterization of a durum alien disomic addition line with enhanced tolerance to Fusarium head blight. Genome. 2009;52:467-83. https://doi.org/10.1139/ G09-014.

33. Jauhar PP, Peterson TS. Toward transferring scab resistance from a diploid wild grass, Thinopyrum elongatum into durum wheat. In: Proceedings of the 2000 National Fusarium Head Blight Forum, pp. 201-204 (Erlanger, Kentucky). Accessed 2000.

34. Jia H, Zhou J, Xue S, Li G, Yan H, Ran C, Zhang Y, Shi J, Jia L, Wang X, Luo J, Ma Z. A journey to understand wheat Fusarium head blight resistance in the Chinese wheat landrace Wangshuibai. Crop J. 2018;6:48-59. https:// doi.org/10.1016/j.cj.2017.09.006

35. Jiang J, Friebe B, Gill BS. Recent advances in alien gene transfer in wheat. Euphytica. 1993;73:199-212. https://doi.org/10.1007/BF00036700.

36. Kage U, Karre S, Kushalappa AC, McCartney C. Identifcation and characterization of a fusarium head blight resistance gene TaACT in wheat QTL-2DL. Plant Biotechnol J. 2017;15:447-57. https://doi.org/10.1111/ pbi.12641.

37. Kalih R, Maurer HP, Hackauf $B$, Miedaner T. Effect of a rye dwarfing gene on plant height, heading stage, and Fusarium head blight in triticale (×Triticosecale Wittmack). Theor Appl Genet. 2014;127:1527-36. https:// doi.org/10.1007/s00122-014-2316-9.

38. Li G, Lang T, Dai G, Li D, Li C, Song X, Yang Z. Precise identification of two wheat-Thinopyrum intermedium substitutions reveals the compensation and rearrangement between wheat and Thinopyrum chromosomes. Mol Breed. 2015;35:2-10. https://doi.org/10.1007/s11032-015-0202-z.

39. Li H, Chen Q, Conner RL, Guo B, Zhang Y, Graf RJ, Laroche A, Jia X, Liu G, Chu C. Molecular characterization of a wheat-Thinopyrum ponticum partial amphiploid and its derivatives for resistance to leaf rust. Genome. 2003;46:906-13. https://doi.org/10.1139/g03-053.

40. Li H, Cui L, Li H, Wang X, Murray TD, Conner RL, Wang L, Gao X, Sun Y, Sun $\mathrm{S}$, Tang W. Effective resources in wheat and wheat-Thinopyrum derivatives for resistance to Heterodera flipjevi in China. Crop Sci. 2012;52:1209-17. https://doi.org/10.2135/cropsci2011.11.0591.

41. Li H, Wang X. Thinopyrum ponticum and Th. intermedium: the promising source of resistance to fungal and viral diseases of wheat. J Genet Genom. 2009;36:557-65. https://doi.org/10.1016/s1673-8527(08)60147-2.

42. Li LH, Li XQ. The Basis of Descriptors and Data Standard for Wild relatives of Wheat. Beijing: Chinese Agricultural Press; 2006.

43. Lin F, Kong ZX, Zhu HL, Xue SL, Wu JZ, Tian DG, Wei JB, Zhang CQ, Ma ZQ. Mapping QTL associated with resistance to Fusarium, head blight in the Nanda2419xWangshuibai population. I. Type II resistance. Theor Appl Genet. 2004;109:1504-11. https://doi.org/10.1007/s00122-004-1772-z.

44. Lin Z, Cui Z, Zeng X, Ma Y, Zhang Z, Nakamura T, Ishikawa G, Nakamura K, Yoshida H, Xin Z. Analysis of wheat-Thinopyrum intermedium derivatives with BYDV-resistance. Euphytica. 2007;158:109-18. https://doi. org/10.1007/s10681-007-9435-1.

45. Liu S, Wang H. Characterization of a wheat-Thinopyrum intermedium substitution line with resistance to powdery mildew. Euphytica. 2005;143:229-33. https://doi.org/10.1007/s10681-005-3862-7.

46. Liu W, Seifers DL, Qi LL, Friebe B, Gill BS. A compensating wheat-Thinopyrum intermedium Robertsonian translocation conferring resistance to wheat streak mosaic virus and Triticum mosaic virus. Crop Sci. 2011:51:2382-90. https://doi.org/10.2135/cropsci2011.03.0118.

47. Liu XL, Wang YJ, Tian ZR, Wang C, Niu LH, Liu ZL, Zhang LD, Chen CH, Zhang RQ, Zhang H, Wang CY, Ji WQ. Molecular identification of FHB resistance gene in varieties derived from common wheat-Thinopyrum ponticum partial amphiploid. Sci Agric Sin. 2017;50:3908-17. https://doi. org/10.3864/j.issn.0578-1752.2017.20.007.

48. Liu ZH, Xu M, Xiang ZP, Li X, Chen WQ, Luo PG. Registration of the novel wheat lines L658, L693, L696, and L699, which are resistance to Fusarium head blight, stripe rust, and powdery mildew. J Plant Regist. 2015;9:1214. https://doi.org/10.3198/jpr2014.01.0003crg.

49. McMullen M, Jones R, Gallenberg D. Scab of wheat and barley: a reemerging disease of devastating impact. Plant Dis. 1997;81:1340-8. https ://doi.org/10.1094/PDIS.1997.81.12.1340.

50. Oliver RE, Xu SS, Stack RW, Friesen TL, Jin Y, Cai X. Molecular cytogenetic characterization of four partial wheat-Thinopyrum ponticum amphiploids and their reactions to Fusarium head blight, tan spot, and Stagonospora nodorum blotch. Theor Appl Genet. 2006;112:1473-9. https://doi. org/10.1007/s00122-006-0250-1.

51. Qi LL, Pumphrey MB, Chen PD, Gill BS. Molecular cytogenetic characterization of alien introgressions with gene Fhb3 for resistance to Fusarium head blight disease of wheat. Theor Appl Genet. 2008;117:1155-66. https ://doi.org/10.1007/s00122-008-0853-9.

52. Rawat N, Pumphrey MO, Liu S, Zhang X, Tiwari VK, Ando K, Trick HN, Bockus WW, Akhunov E, Anderson JA, Gill B. Wheat Fhb1 encodes a chimeric lectin with agglutinin domains and a pore-forming toxinlike domain conferring resistance to Fusarium head blight. Nat Genet. 2016:48:1576-80. https://doi.org/10.1038/ng.3706.

53. Ren JD, Wang Z, Du ZY, Che MZ, Zhang YB, Quan W, Wang YJ, Jiang X, Zhang ZJ. Detection and validation of a novel major QTL for resistance to Fusarium head blight from Triticum aestivum in the terminal region of chromosome 7DL. Theor Appl Genet. 2019;132:241-55. https://doi. org/10.1007/s00122-018-3213-4.

54. Scoles G, Jauhar PP, Peterson TS, Xu SS. Cytogenetic and molecular characterization of a durum alien disomic addition line with enhanced tolerance to Fusarium head blight. Genome. 2009;52:467-83. https://doi. org/10.1139/G09-014.

55. Sears ER, Evans LT, Peacock WJ. Transfer of alien genetic material to wheat. Wheat Science-Today and Tomorrow. 1981; pp. 75-89.

56. Sun SC. The approach and methods of breeding new varieties and new species from Agrotriticum hybrids. Acta Agron Sin. 1981;7:51-7.

57. Tang S, Li Z, Jia X, Larkin PJ. Genomic in situ hybridization (GISH) analyses of Thinopyrum intermedium, its partial amphiploid Zhong 5, and diseaseresistant derivatives in wheat. Theor Appl Genet. 2000;100:344-52. https ://doi.org/10.1007/s001220050045.

58. Wang RC, Larson $S R$, Jensen $K B$, Bushman $B S$, DeHaan $L R$, Wang $S$, Yanac $X$. Genome evolution of intermediate wheatgrass as revealed by EST-SSR markers developed from its three progenitor diploid species. Genome. 2015;58:63-70. https://doi.org/10.1139/gen-2014-0186.

59. Wang RRC, Li XM, Hu ZM, Zhang JY, Larson SR, Zhang XY, Grieve CM, Shannon MC. Development of salinity tolerant wheat recombination 
lines from a wheat disomic addition line carrying a Thinopyrum junceum chromosome. Int J Plant Sci. 2003;164:25-33. https://doi. org/10.1086/344556.

60. Wang $\mathrm{Y}$, Wang $\mathrm{H}$. Characterization of three novel wheat-Thinopyrum intermedium addition lines with novel storage protein subunits and resistance to both powdery mildew and stripe rust. J Genet Genomics 2016;43:45-8. https://doi.org/10.1016/j.jgg.2015.10.004.

61. Wang D, Du P, Pei Z, Zhuang L, Qi Z. Development and application of high resolution karyotypes of "wheat Chinese Spring" aneuploids. Crop J. 2017;43:1575-87. https://doi.org/10.3724/SP.J.1006.2017.01575.

62. Wang HW, Sun SL, Ge WY, Zhao LF, Hou BQ, Wang K, Lyu ZF, Chen LY, Xu SS, Guo J, Li M, Su PS, Li XF, Wang GP, Bo CY, Fang XJ, Zhuang WW, Cheng XX, Wu JW, Dong LH, Chen WY, Li W, Xiao GL, Zhao JX, Hao YC, Xu Y, Gao Y, Liu WJ, Liu YH, Yin HY, Li JZ, Li X, Zhao Y, Wang XQ, Ni F, Ma X, Li AF, Xu SS, Bai GH, Nevo E, Gao CX, Ohm H, Kong LR. HorizontalgenetransferofFhb7 from fungus underlies Fusarium head blight resistance in wheat. Science. 2020. https://doi.org/10.1126/science.aba5435.

63. Xi W, Tang Z, Tang S, Yang Z, Luo J, Fu S. New ND-FISH-positive oligo probes for identifying Thinopyrum chromosomes in wheat backgrounds. Int J Mol Sci. 2019;20(2031):2-8. https://doi.org/10.3390/ijms20082031.

64. Xue S, Li G, Jia H, Xu F, Lin F, Tang M, Wang Y, An X, Xu H, Zhang L, Kong Z, Ma Z. Fine mapping Fhb4, a major QTL conditioning resistance to Fusarium infection in bread wheat (Triticum aestivum L.). Theor Appl Genet. 2010;121:147-56. https://doi.org/10.1007/s00122-010-1298-5.

65. Xue S, Xu F, Tang M, Zhou Y, Li G, An X, Lin F, Xu H, Jia H, Zhang L, Kong Z, Ma Z. Precise mapping Fhb5, a major QTL conditioning resistance to Fusarium infection in bread wheat (Triticum aestivum L.). Theor Appl Genet. 2011;123:1055-63. https://doi.org/10.1007/s00122-011-1647-z.
66. Yang ZJ, Li GR, Chang ZJ, Zhou JP, Ren ZL. Characterization of a partial amphiploid between Triticum aestivum cv. Chinese Spring and Thinopyrum intermedium ssp. trichophorum. Euphytica. 2006;149:11-7. https:// doi.org/10.1007/s10681-005-9010-6.

67. Zeng J, Cao W, Fedak G, Sun S, Mccallum B, Fetch T, Xue A, Zhou Y. Molecular cytological characterization of two novel durum-Thinopyrum intermedium partial amphiploids with resistance to leaf rust, stem rust and Fusarium head blight. Hereditas. 2013;150:10-6. https://doi.org/10.11 11/j.1601-5223.2012.02262.x.

68. Zhang H, Bian Y, Gou X, Zhu B, Xu C, Qi B, Li N, Rustgi S, Zhou H, Han F, Jiang J, von Wettstein D, Liu B. Persistent whole chromosome aneuploidy is generally associated with nascent allohexaploid wheat. Proc Natl Acad Sci. 2013;110:3447-52. https://doi.org/10.1073/pnas.1300153110.

69. Zhang H, Mittal N, Leamy LJ, Barazani O, Song B. Back into the wild-apply untapped genetic diversity of wild relatives for crop improvement. Evol Appl. 2017;10:5-24. https://doi.org/10.1111/eva.12434.

70. Zhang X, Zhou M, Ren L, Bai G, Ma H, Scholten OE, Guo P, Lu W. Molecular characterization of Fusarium head blight resistance from wheat variety Wangshuibai. Euphytica. 2004;139:59-64. https://doi.org/10.1007/s1068 1-004-2298-9.

\section{Publisher's Note}

Springer Nature remains neutral with regard to jurisdictional claims in published maps and institutional affiliations.
Ready to submit your research? Choose BMC and benefit from:

- fast, convenient online submission

- thorough peer review by experienced researchers in your field

- rapid publication on acceptance

- support for research data, including large and complex data types

- gold Open Access which fosters wider collaboration and increased citations

- maximum visibility for your research: over $100 \mathrm{M}$ website views per year

At BMC, research is always in progress.

Learn more biomedcentral.com/submissions 